\title{
Aktivitas Antioksidan, Kadar Protein, dan Gula Reduksi Yoghurt Susu Kambing dengan Penambahan Sari Apel Manalagi (Malus sylvestris)
}

\section{Antioxidant Activity, Protein Levels, and Reducing Sugar of Goat Milk Yoghurt with Manalagi Apple (Malus sylvestris)}

\author{
O. R. Puspitarini* dan S. Susilowati \\ Fakultas Peternakan, Universitas Islam Malang, Malang - Indonesia \\ *Corresponding E-mail: oktaviarahayu@unisma.ac.id \\ (Diterima: 27 Maret 2020; Disetujui: 23 Mei 2020)
}

\begin{abstract}
ABSTRAK
Tujuan penelitian ini adalah menganalisis pengaruh penambahan sari apel Manalagi terhadap aktivitias antioksidan, kadar protein, dan gula reduksi yoghurt susu kambing. Materi yang digunakan adalah susu kambing, stater komersial, sari apel Manalagi. Metode penelitian ini adalah eksperimental dengan rancangan acak lengkap 5 perlakuan dan 4 ulangan. Perlakuannya adalah penambahan sari apel $0 \%(\mathrm{P} 0)$, 4\% (P1), 6\% (P2), 8\% (P3), dan 10\% (P4). Analisis data menggunakan analisis ragam apabila ada pengaruh maka dilanjutkan dengan uji Duncan. Hasil penelitian menunjukkan bahwa penambahan sari apel Manalagi tidak berpengaruh $(\mathrm{P}<0,05)$ terhadap aktivitas antioksidan, kadar protein, dan gula reduksi. Penambahan $4 \%$ sari apel dalam yoghurt susu kambing menghasilkan aktivitas antioksidan sebesar 80,26\%, kadar protein $4,18 \%$, dan gula reduksi $3,44 \%$. Simpulan penelitian ini adalah penambahan sari apel Manalagi sebanyak $4-10 \%$ tidak berpengaruh terhadap aktivitas antioksidan, kadar protein, dan gula reduksi yoghurt susu kambing. Perlu adanya penambahan konsentrasi sari apel Manalagi lebih dari 10\% sehingga dapat digunakan untuk memperbaiki kualitas yoghurt susu kambing.
\end{abstract}

Kata kunci: yoghurt kambing, apel Manalagi, aktivitas antioksidan, kadar protein, gula reduksi

\section{ABSTRACT}

This research aims to analyze the effect of Manalagi apple on antioxidant activity, protein content, and sugar reduction goat milk yogurt. The material used goat milk, commercial starter, Manalagi apple. The method was used experimentally with a completely randomized design, five treatments and four replications. The treatments were the addition of $0 \%(P 0), 4 \%(P 1), 6 \%(P 2), 8 \%(P 3)$, and $10 \%(P 4)$ Manalagi apple. Data analysis used analysis of variance if there was an influence then proceed with the Duncan test. The results showed that the addition of Manalagi apple did not affect $(P<0,05)$ the antioxidant activity, protein levels, and reducing sugars. The addition of $4 \%$ Manalagi apple in goat's milk yogurt resulted in $80.26 \%$ antioxidant activity, $4.18 \%$ protein levels, and $3.44 \%$ reduction sugar. The conclusion of this research is the addition of 4-10\% Manalagi apple doesn't affect the antioxidant activity, protein levels, and reduction of sugar in goat milk yogurt. It is necessary to increase the concentration of Manalagi apple more than $10 \%$ so that it can be used to improve the quality of goat milk yogurt.

Keywords: goat yogurt, Manalagi apple, antioxidant activity, protein levels, reducing sugar

\section{PENDAHULUAN}

Susu kambing adalah salah satu produk hasil ternak kambing peranakan ettawa (PE). Susu kambing PE ini mengandung nutrient mendekati Air Susu Ibu (ASI). Susu kambing memiliki keunggulan dibandingkan dengan susu sapi, selain dari segi nutrient, ukuran globula lemaknya lebih kecil. Hal ini menyebabkan susu kambing aman dikonsumsi konsumen yang memiliki riwayat tidak mampu mencerna gula susu dengan 
baik. Susu kambing yang disimpan pada suhu ruang mampu bertahan hingga 5 jam (Sutrisna et al., 2014) dan detahanan susu kambing yang telah dipasteurisasi dan disimpan pada suhu refrigerator adalah 9 hari dengan kandungan protein $4,16 \%$, lemak $6,83 \%$, dan solid non fat $8,29 \%$.

Teknologi pengolahan susu tidak hanya dilakukan dengan pemanasan (pasteurisasi). Teknologi lain yang dapat dilakukan adalah teknologi fermentasi. Teknologi fermentasi adalah salah satu proses pengolahan susu dengan bantuan bakteri asam laktat (BAL). BALiniberperanpositifdidalamtubuhmanusia salah satunya membunuh bakteri pathogen dan memperlancar proses pencernaan. Jenis BAL dalam pengolahan produk fermentasi susu ini adalah Lactobacillus bulgaricus, Lactobacillus acidhopillus, dan Streptococcus thermophillus. Peran BAL di dalam proses pembentukan yoghurt adalah memanfaatkan gula yang terdapat di dalam susu (laktosa) untuk dipecah menjadi asam laktat sehingga yoghurt yang dihasilkan memiliki rasa asam. Menurut Zain dan Kuntoro (2017) bahwa yoghurt kambing dengan penambahan bakteri asam laktat berupa Lactobacillus acidophillus (La) menghasilkan jumlah BAL $9 \log ^{10} \mathrm{CFU} /$ $\mathrm{ml}$ dengan total asam tertitrasi sebanyak $1,74 \%$. Adanya penambahan probiotik $L a$ ini mampu mempertahankan populasi BAL di dalam yoghurt susu kambing.

Mekanisme kerja BAL di dalam proses pembentukan yoghurt perlu dioptimalkan salah satunya dengan penambahan gula selain gula susu baik gula tebu maupun gula dari sari buah. Menurut Wardani et al. (2017) bahwa sari buah nanas mengandung gula yang mampu meningkatkan aktivitas BAL dan meningkatkan kualitas organoleptik soyghurt. Menurut Pratangga et al. (2019) semakin tinggi penambahan level sukrosa dan fruktosa mampu meningkatkan total BAL dan menurunkan nilai $\mathrm{pH}$ yoghurt susu kambing. Yoghurt susu kambing tanpa adanya tambahan gula sukrosa maupun fruktosa mencapai jumlah BAL $7 \log ^{10} \mathrm{CFU} / \mathrm{ml}$ sedangkan total BAL yoghurt dengan penambahan sukrosa hingga level $8 \%$ mencapai $7,2 \log ^{10} \mathrm{CFU} / \mathrm{ml}$.

Berdasarkan hal tersebut perlu adanya penambahan gula selain laktosa untuk menunjang pertumbuhan BAL, salah satunya dengan penambahan gula dari sari buah apel Manalagi. Apel Manalagi ini merupakan salah satu jenis apel favorit pilihan konsumen dan menjadi salah satu buah khas kota Malang, Jawa Timur. Apel Manalagi memiliki warna daging buah kuning keputihan. Kadar airnya mencapai $84,05 \%$. Tekstur apel manalagi lebih keras dibandingkan dengan apel Anna dan apel Rome beauty (Sufrida et al., 2004). Apel Manalagi sebanyak 100 gram mengandung fruktosa $4,5 \mathrm{~g}$, gula pereduksi $6,96 \mathrm{~g}$, total gula $8,29 \mathrm{~g}$, aktivitas antioksidan $6,53 \mathrm{~g}$, dan vitamin C 6,60mg (Sa'adah dan Estiati, 2015). Adanya kandungan fruktosa, gula pereduksi dan senyawa antioksidan di dalam buah apel Manalagi ini diduga mampu memperbaiki kualitas yoghurt susu kambing yang dihasilkan dari segi aktivitas antioksidan, kadar protein, dan gula reduksi sehingga perlunya penelitian ini untuk dilakukan.

Tujuan penelitian ini adalah untuk menganalisis aktivitas antioksidan, kadar protein, dan gula pereduksi yoghurt susu kambing dengan penambahan sari apel Manalagi. Manfaat lain dalam penelitian ini adalah memvariasikan produk yoghurt dengan bahan tambahan buah lokal khas daerah Malang yaitu apel Manalagi sehingga dapat diaplikasikan langsung kepada masyarakat dan memberikan informasi mengenai level penambahan sari apel Manalagi yang tepat untuk pembuatan yoghurt susu kambing sehingga berkualitas untuk tubuh.

\section{METODE}

Penelitian ini dilakukan di Laboratorium Teknologi Hasil Ternak, Universitas Islam Malang pada bulan November 2019. Materi yang digunakan dalam penelitian ini adalah susu kambing segar, stater komersiil, apel Manalagi.

Metode yang digunakan dalam 
penelitian ini adalah eksperimental menggunakan rancangan acak lengkap (RAL) dengan 5 perlakuan dan 4 ulangan. Perlakuannya adalah P0 (yoghurt tanpa penambahan sari apel), P1 (yoghurt dengan penambahan sari apel 4\% (v/v)), P2 (yoghurt dengan penambahan sari apel $6 \%(\mathrm{v} / \mathrm{v}))$, P3 (yoghurt dengan penambahan sari apel $8 \%$ (v/v)), dan P4 (yoghurt dengan penambahan sari apel 10\% (v/v)).

\section{Prosedur Pembuatan Sari Apel}

Pembuatan sari apel Manalagi menurut Al-Baarri dan Legowo (2012) dengan modifikasi sebagai berikut: Mencuci apel Manalagi yang telah diperoleh dari petani apel di wilayah Malang dengan air mengalir; Menghilangkan biji dan kulit apel Manalagi; Memotong apel Manalagi menjadi bagian yang sama bentuk dengan ukuran sekitar $3 \times 3$ $\mathrm{cm}$; Menghancurkan bagian apel yang telah terpotong ke dalam blender sampai hancur; Menyaring hasil blender dan mengambil hasil saringannya; Memisahkan endapan dan sarinya menggunakan sentrifus dengan kecepatan $6000 \mathrm{rpm}$ selama 5 menit; dan mengumpulkan hasil sentrifus sari apel Manalagi.

\section{Pembuatan yoghurt susu}

Pembuatan yoghurt Menurut Legowo (2009) dengan modifikasi, sebagai berikut: Melakukan proses pasteurisasi susu kambing pada suhu $80^{\circ} \mathrm{C}$ selama 15 menit; Menurunkan suhu susu kambing pasteurisasi hingga $43^{\circ} \mathrm{C}$; Menginokulasikan starter komersial sebanyak $4 \%(\mathrm{v} / \mathrm{v})$ dari volume susu kambing; Menggoyang campuran susu kambing dengan starter hingga homogen kemudian menginkubasi selama 3 jam pada suhu $43^{\circ} \mathrm{C}$; Menambahkan sari apel Manalagi sesuai perlakuan masing-masing $(0,4,6$, $8,10 \%$ ) dari volume total susu kambing; Menghomogenkan kembali campuran susu kambing, stater dan sari apel sampai tercampur rata; Melanjutkan proses inkubasi kembali pada suhu $43^{\circ} \mathrm{C}$ selama 2 jam, dan Produk yoghurt susu kambing sebagai sampel telah siap untuk diuji.

\section{Pengujian Parameter}

Pengujian aktivitas antioksidan menggunakan metode DPPH. Pengujian protein menggunakan metode semi microkjeldahl. Pengujian gula reduksi menggunakan metode nelson somogyi spectrofotometri.

\section{Analisis Data}

Data yang diperoleh dianalisis menggunakan ANOVA. Apabila terdapat pengaruh maka dilanjutkan dengan Duncan Multiple Range Test (DMRT).

\section{HASIL DAN PEMBAHASAN}

\section{Aktivitas Antioksidan}

Berdasarkan hasil analisis ragam menyatakan bahwa penambahan konsentrasi sari apel manalagi 4, 6, 8, dan 10\% tidak berpengaruh $(p<0,05)$ terhadap aktivitas antioksidan yoghurt susu kambing. Rerata aktivitas antioksidan yang dihasilkan dari yoghurt susu kambing dengan penambahan sari apel 4, 6, 8, dan $10 \%$ berkisar $80-55,97 \%$ (Tabel 1). Aktivitas antioksidan yoghurt susu kambing tanpa adanya penambahan sari apel nya tergolong tinggi yaitu 97\%. Menurut Wakhidah et al. (2017) bahwa yoghurt susu sapi tanpa penambahan ekstrak jahe memiliki aktivitas antioksidan sebesar 0,994\% sedangkan dengan adanya penambahan 7,5\% ekstrak jahe pada yoghurt susu sapi aktivitas antioksidannya meningkat sebesar 3,446\%. Menurut Hui et al. (2015) bahwa aktivitas antioksidan yoghurt susu sapi $19,25 \%$ dan meningkat seiring dengan penambahan konsentrasi ekstrak rumput laut hingga $68,30 \%$ sedangkan yoghurt komersial hanya sebesar $6,08 \%$.

Permatasari (2018) menyatakan bahwa semakin tinggi penambahan yoghurt susu kambing ke dalam sediaan lotion maka meningkatkan aktivitas antioksidannya. Hal ini dikarenakan susu kambing mempunyai karotenoid dan flavonoid yang berfungsi sebagai senyawa antioksidan dan adanya senyawa bioaktif peptida dari hasil fermentasi 
Tabel 1. Rerata nilai aktivitas antioksidan, kadar protein, dan gula reduksi yoghurt susu kambing dengan penambahan sari apel

\begin{tabular}{|c|c|c|c|c|c|c|}
\hline \multirow{2}{*}{ No. } & \multirow{2}{*}{ Parameter $^{\text {ns }}$} & \multicolumn{5}{|c|}{ Konsentrasi sari apel manalagi (\%) } \\
\hline & & 0 & 4 & 6 & 8 & 10 \\
\hline 1. & $\begin{array}{l}\text { Aktivitas } \\
\text { antioksidan }\end{array}$ & $97,29 \pm 1,89$ & $80,26 \pm 1,40$ & $69,00 \pm 1,09$ & $61,99 \pm 1,07$ & $55,97 \pm 0,74$ \\
\hline 2. & Kadar protein & $3,78 \pm 0,11$ & $4,18 \pm 0,08$ & $4,56 \pm 0,12$ & $4,99 \pm 0,11$ & $5,43 \pm 0,17$ \\
\hline 3. & Gula reduksi & $3,65 \pm 0,10$ & $3,44 \pm 0,32$ & $3,01 \pm 0,09$ & $3,00 \pm 0,12$ & $2,84 \pm 0,08$ \\
\hline
\end{tabular}

Keterangan: $\mathrm{ns}=$ non signifikan

yoghurt. Aktivitas antioksidan yoghurt pada susu kambing tinggi, hal ini dikarenakan yoghurt susu kambing memiliki senyawa antioksidan. Oleh karena itu, aktivitas antioksidan yoghurt susu kambing lebih tinggi dibandingkan dengan yoghurt susu sapi. Dengan tingginya aktivitas antioksidan ini maka produk yoghurt ini bagus untuk dikonsumsi sebagai produk pangan untuk menangkal radikal bebas yang ada di dalam tubuh manusia. Menurut Wibawanti dan Rinawidiastuti (2018) bahwa yoghurt drink susu kambing plus ektrak kulit manggis digunakan sebagai produk minuman fungsional untuk kesehatan tubuh. Yoghurt dapat dimanfaatkan sebagai alternatif makanan selingan untuk mencegah stress oksidatif. Hal ini dikarenakan yoghurt dengan aktivitas antioksidannya mampu menurunkan cekaman stess (Lingga, 2012)

Penambahan sari apel hingga 10\% tidak berpengaruh terhadap aktivitas antioksidan yoghurt susu kambing. Hal ini dimungkinkan proses pengambilan senyawa antioksidan sari apel yang kurang tepat sehingga senyawa antioksidannya kurang mampu berefek ketika diolah menjadi produk yoghurt. Faktor lain juga berasal dari kualitas buah apel yang digunakan. Apel Manalagi merupakan salah satu buah yang mengandung senyawa antioksidan. Menurut Sa'adah dan Estiati (2015) bahwa buah apel mengandung senyawa antioksidan sebesar $6,53 \mathrm{~g}$ dan vitamin C $6,60 \mathrm{mg}$. Antioksidan adalah senyawa yang dapat mengganggu reaksi radikal bebas seperti reaksi oksidasi lipida. Aktivitas antioksidan yoghurt dengan penambahan sari apel dan madu berkisar 27,10-32,83\%. Aktivitas antioksidan tertinggi didapatkan pada yoghurt dengan penambahan $20 \%$ sari apel rome beauty dan 5\% madu. Faktor tingginya nilai aktivitas antioksidan ini dipengaruhi adanya variasi sari apel dan madu (Rosiana dan Khoiriyah, 2018)

\section{Kadar Protein}

Berdasarkan hasil analisis ragam menyatakan bahwa penambahan konsentrasi sari apel manalagi $4,6,8$, dan $10 \%$ tidak berpengaruh $(\mathrm{P}<0,05) \quad$ terhadap kadar protein yoghurt susu kambing. Rata-rata kadar protein yoghurt susu kambing dengan penambahan sari apel Manalagi meningkat seiring bertambahnya konsentrasi. Rata-rata kadar protein yoghurt susu kambing tanpa penambahan sari apel Manalagi sebesar 3,78\% sedangkan rata-rata kadar protein yoghurt susu dengan penambahan $4,6,8,10 \%$ sari apel Manalagi sebesar 4,18-5,43\% (Tabel 1). Kadar protein yoghurt susu kambing yang dihasilkan dalam penelitin ini sesuai dengan syarat mutu produk yoghurt yang ditetapkan oleh Badan Standarisasi Nasional, SNI 2981:2009 kadar protein yoghurt minimal 2,7\% (BSN, 2009). Yoghurt susu kambing dengan penambahan ekstrak kayu manis 4-5\% menghasilkan kadar protein sebesar 3,84-4,16\% (Lindasari et al., 2013).

\section{Gula Reduksi}

Berdasarkan hasil analisis ragam menyatakan bahwa penambahan konsentrasi sari apel manalagi 4, 6, 8, dan 10\% tidak berpengaruh $(\mathrm{P}<0,05)$ terhadap gula reduksi yoghurt susu kambing. Rata-rata gula reduksi 
yoghurt susu kambing tanpa sari apel Manalagi $3,65 \%$ dan gula reduksi yoghurt susu kambing dengan $4-10 \%$ sari apel Manalagi sebesar 2,84-3,44\% (Tabel 1). Berdasarkan kadar gula reduksi dalam yoghurt tersebut maka yoghurt yang dihasilkan termasuk golongan produk makanan rendah gula. Menurut Rosiana dan Khoiriyah (2018) bahwa yoghurt merupakan pangan rendah gula. Sa'adah dan Estiati (2015) apel Manalagi mengandung gula reduksi $6,96 \mathrm{~g}$, fruktosa $4,5 \mathrm{~g}$, glukosa $3,72 \mathrm{~g}$ dalam $100 \mathrm{~g}$ buah.

Hasil penelitian menunjukkan seiring bertambahnya konsentrasi sari apel manalagi maka kadar gula reduksi semakin menurun. Hal ini dimungkinkan adanya adanya kandungan fruktosa dan glukosa di dalam sari apel yang banyak banyak dimanfaatkan untuk pertumbuhan bakteri asam laktat di dalam proses fermentasi sehingga gula reduksi yang dihasilkan pada produk yoghurt semakin menurun seiring bertambahnya konsentrasi sari apel selain laktosa yang terdapat dalam susu kambing itu sendiri. Menurut Lindasari et al. (2013) laktosa susu kambing berfungsi sumber energi utama bagi bakteri asam laktat, kadar gula dalam yoghurt susu kambing dengan penambahan ekstrak kayu manis menurun seiring bertambahnya konsentrasi ekstrak kayu manis. Hal ini disebabkan terjadinya pengenceran gula di dalam produk dan dimanfaatkan oleh bakteri asam laktat sehingga kandungan gula semakin rendah. Menurut Sudarmadji (2007) bahwa gula reduksi merupakan gula yang mampu mereduksi karena memiliki gugus keton bebas seperti glukosa dan fruktosa.

\section{KESIMPULAN}

Penambahan sari apel Manalagi 4-10\% tidak mempengaruhi aktivitas antioksidan, kadar protein, dan gula reduksi yoghurt susu kambing. Perlu adanya penambahan sari apel Manalagi sehingga berpotensi sebagai sumber gula buah baik untuk memperbaiki kualitas yoghurt susu kambing.

\section{UCAPAN TERIMA KASIH}

Terima kasih kepada Lembaga Penelitian dan Pengabdian Kepada Masyarakat Universitas Islam Malang atas pendanaan Hibah Institusi Unisma skim klasterisasi penelitian tahun 2019-2020.

\section{DAFTAR PUSTAKA}

Al-Baarri, A. N. dan A. M. Legowo. 2012. Aplikasi Teknologi Lactoperoxidase Sepharose Membrane Sebagai Metode Pengawetan Susu Segar yang Murah dan Aman. (Hasil penelitian tidak dipublikasikan).

Badan Standarisasi Nasional. 2009. SNI 2981:2009. Yoghurt. Badan Standarisasi Nasional, Jakarta.

Husni, A., M. Madalena, dan Ustadi. 2015. Aktivitas antioksidan dan tingkat peneriamaan konsumen pada yoghurt yang diperkaya dengan ekstrak Sargassum polycystum. JPHPI. 18(2): 108-118.

Legowo, A. M., Kusrahayu, dan S. Mulyani. 2009. Teknologi Pengolahan Susu. BP Universitas Diponegoro, Semarang.

Lindasari, F., R. R. A. Maheswari., A. Atabany, dan M. S. Soenarno. 2013. Karakteristik yogurt probiotik ekstrak kayu manis dari susu kambing hasil pemberian pakan campuran garam karboksilat kering. J. Ilmu Produksi dan Teknologi Peternakan. 1(2): 80-87.

Lingga, L. 2012. Bebas Diabetes Tipe-2 Tanpa Obat (1 st ed). PT Agromedia Pustaka, Jakarta.

Permatasari,A. P. 2018. Pengaruh penambahan yoghurt susu kambing terhadap lotion ditinjau dari sifat antioksidan. Thesis. Universitas Brawijaya. Malang.

Pratangga, D. A., S. Susilowati, dan. O. R. Puspitarini. 2019. Pengaruh penambahan berbagai level sukrosa 
dan fruktosa terhadap total bakteri asam laktat dan nilai $\mathrm{pH}$ yoghurt susu kambing. $J$ Rekasatwa Peternakan 2(1): 51-56.

Puspitarini, O. R. dan M. Herbani. 2018. Kadar protein, kadar lemak dan solid non fat susu kambing pasteurisasi pada penyimpanan refrigerator. J Aplikasi Teknologi Pangan. 7(1): 12-14.

Rosiana, N. M. dan T. Khoiriyah. 2018. Yoghurt Tinggi Antioksidan dan Rendah Gula dari Sari Buah Apel Rome Beauty dan Madu. JITEK. 13(2): 81-90.

Sa'adah dan T. Estiasih. 2015. Karakteristik Minuman Sari Apel Produksi Skala Mikro dan Kecil di Kota Batu. Jurnal Pangan dan Agroindustri. 3(2): 374380.

Sudarmadji, S., B. Haryono, dan Suhardi. 2007. Prosedur Analisa untuk Bahan Makanan dan Pertanian. Liberty, Yogyakarta.

Sufrida, Y., Irlansyah., Edi, J. dan Mofatis W. 2004. Khasiat dan Manfaat Apel. Agromedia, Jakarta.

Sutrisna, D. Y., Suada, I. K. dan Sampurna, I. P. 2014. Kualitas susu kambing selama penyimpanan suhu ruang berdasarkan berat jenis, uji didih dan kekentalan. Indonesia Medicus Veterinus. 3(1): 6067.

Wakhidah, N., Godras J. M. dan R. Utami. 2017. Yoghurt susu sapi dengan penambahan ekstrak ampas jahe dari destilasi minyak atsiri. Proceeding Biology Education Conference. Oktober 2017. 14(1): 278-284.

Wardani, E. K., S. Zulaekah, dan E. Purwani. 2017. Pengaruh penambahan sari buah nanas (Ananas comosus) terhadap jumlah bakteri asam laktat (BAL) dan nilai $\mathrm{pH}$ soyghurt. J. Kesehatan. 10(1): 68-74.

Wibawanti, J. M. W. dan Rinawidiastuti. 2018. Sifat fisik dan organoleptik yogurt drink susu kambing dengan penambahan ekstrak kulit manggis. J Imu dan Teknologi Hasil Ternak. 13(1): 27-37.

Zain, W. N. H. dan B. Kuntoro. 217. Karakteristik mikrobiologis dan fisik yogurt susu kambing dengan penambahan probiotik Lactobacillus acidophilus. J. Ilmu-ilmu peternakan 20(1): 1-8. 